\title{
PHYSICAL-CHEMICAL QUALITY OF A LATOSSOL UNDER DIRECT SEEDING AND SOYBEAN-CORN SUCCESSION IN THE CERRADO-AMAZONIAN ECOTONE ${ }^{1}$
}

\author{
ONÃ DA SILVA FREDDI²*, RENAN FRANCISCO RIMOLDI TAVANTI ${ }^{2}$, MATHEUS BORTOLANZA SOARES ${ }^{2}$, \\ FREDERICO TERRA DE ALMEIDA ${ }^{2}$, FERNANDA SALLES CUNHA PERES ${ }^{3}$
}

\begin{abstract}
The soybean-corn succession in no-tillage system (DSS) is the most common cultivation practice in the state of Mato Grosso. Soils submitted to this type of system are prone to the formation of fertility gradients and surface compaction, restricting crop productivity. The objective of this work was to evaluate the physical-chemical attributes of an Oxisol after 11 years of continuous succession of soybean and corn in direct seeding, using geostatistical analysis techniques and main components. The experiment was conducted at the Chão Nativo farm located in the municipality of Sinop, Mato Grosso, Cerrado-Amazonian ecotone. For this, a rectangular mesh was installed with 103 sampling points distributed in an area of 7.02 ha, in which the grain yield of the soybean was determined as well as the physical and chemical attributes of the soil in the layers $0-10$ and $0.10-0.20 \mathrm{~m}$. Soybean showed a grain yield between 2.83 and $3.70 \mathrm{Mg} \mathrm{ha}^{-1}$, which was positively correlated with the spatial distribution of $\mathrm{pH}$, phosphorus and potassium. The soil presented low physical quality due to high soil resistance to penetration and macroporosity less than $10 \%$; however, no spatial correlation of physical attributes with soybean yield was observed.
\end{abstract}

Keywords: Glycine max L.. Soil Penetration Resistance. Soil fertility. Macroporosity.

\section{QUALIDADE FÍSICO-QUÍMICA DE UM LATOSSOLO SOB SEMEADURA DIRETA E SUCESSÃO SOJA-MILHO NO ECÓTONO CERRADO/AMAZÔNIA}

\begin{abstract}
RESUMO - A sucessão soja-milho em semeadura direta (SSD) é a prática de cultivo mais comum no estado de Mato Grosso. Os solos submetidos a este tipo de sistema estão propensos à formação de gradientes de fertilidade e compactação superficial, restringindo a produtividade das culturas. O objetivo do trabalho foi avaliar os atributos físico-químicos de um Latossolo Vermelho-Amarelo após 11 anos de sucessão contínua de soja e milho em semeadura direta, utilizando-se técnicas de análise geoestatística e componentes principais. O experimento foi conduzido na fazenda Chão Nativo localizada no município de Sinop, Mato Grosso, ecótono Cerrado-Amazônia. Para isso instalou-se uma malha retangular com 103 pontos amostrais distribuídos em uma área de 7,02 ha, nos quais se determinou a produtividade de grãos da soja e os atributos físicos e químicos do solo nas camadas de 0-10 e 0,10-0,20 m. A soja apresentou amplitude na produtividade de grãos entre 2,83 e $3,70 \mathrm{Mg} \mathrm{ha}^{-1}$, que foi correlacionada de forma positiva com a distribuição espacial do $\mathrm{pH}$, fósforo e potássio. $\mathrm{O}$ solo apresentou baixa qualidade física devido a elevada resistência do solo à penetração e macroporosidade menor que $10 \%$, contudo, não foi observada correlação espacial dos atributos físicos com a produtividade da soja.
\end{abstract}

Palavras-chave: Glycine max L.. Resistência do solo à penetração. Fertilidade do solo. Macroporosidade.

${ }^{2}$ Institute of Agricultural and Environmental Sciences, Universidade Federal de Mato Grosso, Sinop, MT, Brazil; onafreddi@gmail.com, renan.tavanti@hotmail.com, matheus2525@hotmail.com, fredterr@gmail.com.

${ }^{3}$ Biodiversity and Biotechnology Network of the Legal Amazon, Universidade Estadual de Mato Grosso, Sinop, MT, Brazil; fernandasallesc@gmail.com.
} 


\section{INTRODUCTION}

The Center-West region of Brazil covers approximately 23.5 million hectares of the cultivated area (CONAB, 2016). One of the production systems involves the cultivation of soybeans followed by maize as the second crop in a direct seeding system, with the fertilization carried out by hauling, furrowing or integrating the two practices. However, it was observed that in large farms, characteristic of this region, the application of fertilizers was carried out preferentially by hauling, due to the greater operational efficiency of the seeding.

Thus, soil fertility usually departs from the ideal, since the direct seeding system provides changes in the vertical and horizontal variability of soils, especially for phosphorus (SANTOS; GATIBONI; KAMINSKI, 2008).

According to Jesus Lacerda et al. (2015), the monitoring of nutrient availability, especially of phosphorus and potassium, is indispensable to increasing the technical and economic efficiency of fertilization in improved fertility soils, with maize being more susceptible to fertilization than soybeans in the direct seeding system, responding economically even in conditions of high fertility in Cerrado soil.

Another critical factor of this production system is the soil compaction which occurs as a result of the soybean harvesting and corn sowing operations which are carried out in rainy periods, usually in late January or early February. These procedures tend to reduce macroporosity and total soil porosity, reducing water infiltration and plant availability (STRECK et al., 2004). According to Luciano et al. (2012), the use of machines and implements under high humidity tends to compact the soils, water acts as a lubricant between the particles thereby reducing their cohesion, allowing sliding and packaging when subjected to some kind of pressure.
According to Valadão et al. (2015), changes in soil physical properties by compaction reduced phosphorus diffusivity, resulting in lower uptake by plants. The authors also verified that the application of fertilizer by hauling restricted root growth in depth, when compared to fertilization by furrowing.

It is well known that agriculture in Brazil has advanced in the direction of the north, leaving areas of Cerrado and penetrating areas of the Amazon Forest. Understanding the impact of this production system on the soils of this biome is necessary for the definition of zones of management and correction of factors limiting productivity in a localized way, thereby generating economic and environmental benefits.

Thus, the objectives of this study are as follows: i) to evaluate the physical and chemical properties/attributes of the soil after 11 years of continuous succession of soybean and corn in the direct seeding of the Cerrado / Amazon ecotone; ii) to analyze the main components as well as synthesize and group the soil properties; iii) to characterize and map the spatial distribution of the main components and their correlation with soybean yield.

\section{MATERIAL AND METHODS}

The experiment was conducted at Fazenda Chão Nativo, municipality of Sinop, northern Mato Grosso State, located in the Cerrado-Amazonian ecotone, with geographic coordinates $11^{\circ} 48^{\prime} 14.64^{\prime \prime}$ $\mathrm{S}, 55^{\circ} 34^{\prime} 55.93^{\prime \prime} \mathrm{W}$ and $367 \mathrm{~m}$ altitude (Figure 1). The climate of the region, according to the classification of Köppen is of type Aw (tropical), with average annual temperature of $24.7^{\circ} \mathrm{C}$ and average annual precipitation of $1975 \mathrm{~mm}$ (SOUZA et al., 2013).

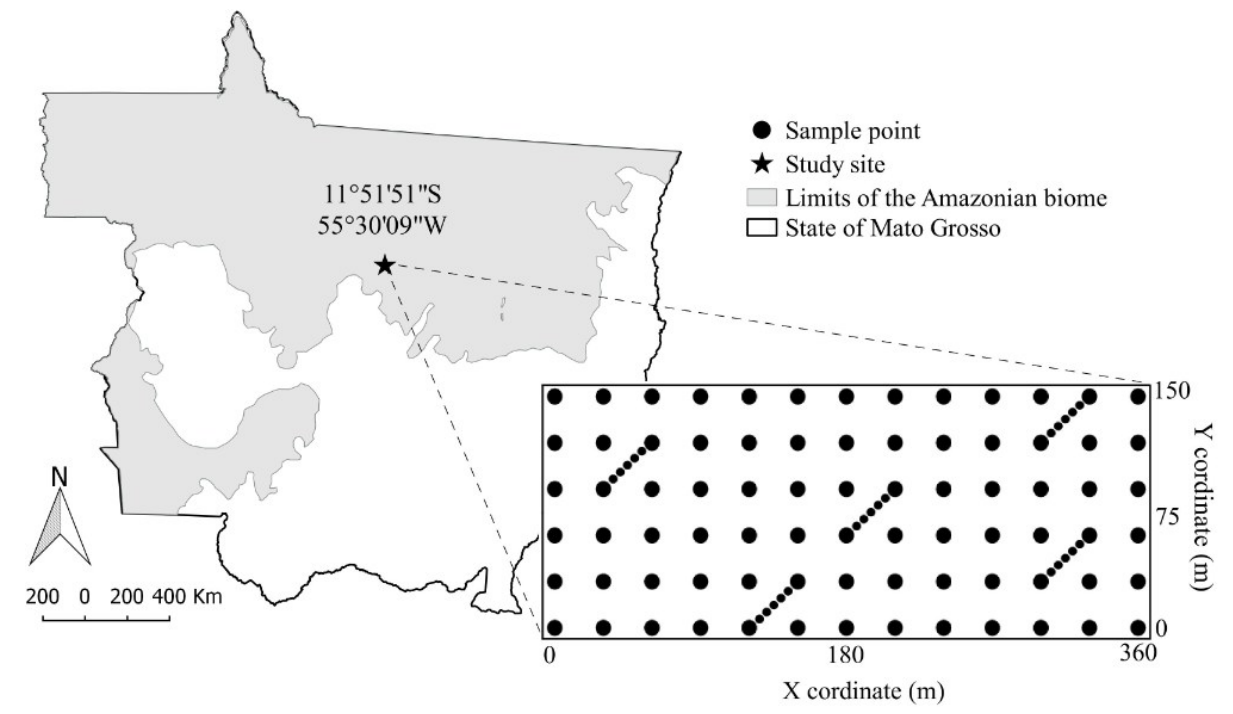

Figure 1. Identification of the study site in southern Amazonia, State of Mato Grosso; sampling scheme. 
The soil of the site is classified as a Red-Yellow Dystrophic Latosol (EMBRAPA, 2014), corresponding to a clayey Udox (SOIL SURVEY STAFF, 2014), with contents of $501 \mathrm{~g} \mathrm{~kg}^{-1}$ of clay, $143 \mathrm{~g} \mathrm{~kg}^{-1}$ of silt and $356 \mathrm{~g} \mathrm{~kg}^{-1}$ of sand in the 0-0.20 m layer.

From its opening until 1998, the area was used in a grazing system (Brachiaria brizantha). At the beginning of 1999, the conventional soil preparation for rice sowing (Oryza sativa L.) was conducted for the 1999 / 2000 cropping season. Since then, for the next 11 years the area has been cultivated with soybean (Glycine max L.) and maize (Zea mays L.) in continuous succession, using the direct seeding (DSS) system.

The chemical management of weeds occurred homogeneously in all areas following the recommendations for the soybean crop. In this study, the Pionner 98Y70 transgenic cultivar was utilized, and the sowing was carried out by means of a Valtra $100 \mathrm{cv} 4 \mathrm{x} 4$ tractor set and Jumil model Magnum 2850 PD of 8 lines, adjusted for a spacing of $0.55 \mathrm{~m}$ with sowing density of 10.5 seeds per meter. After sowing, fertilization with $400 \mathrm{~kg} \mathrm{ha}^{-1}$ of the 0-18-18 formulation was carried out. Phytosanitary treatments were performed according to the technical recommendations for soybean cultivation.

For data sampling, a rectangular mesh was built consisting of 6 rows and 13 columns, containing 78 sample points, spaced $30 \mathrm{~m}$ by $30 \mathrm{~m}$ in both axes, totaling a study area of 7.02 ha. In addition, 25 points of refinement were allocated within the mesh, aiming to detail the study of the spatial dependence of the data between the points of $30 \mathrm{~m}$. A total of 103 points were obtained by adding the points of the mesh and the points of refinement (Figure 1).

At all sample points, samples of the preserved structure and deformed structure were collected to analyze the soil physical and chemical properties, both in the 0-0.10 and 0.10-0.20 m layers.

The preserved structure samples were extracted by means of volumetric rings measuring $0.05 \mathrm{~m}$ in height and $0.05 \mathrm{~m}$ in diameter. In the laboratory, they were saturated by gradually raising a water slide on a tray, and then subjected to a tension of $100 \mathrm{hPa}$ on a tension table. After drainage stabilization, the water content at $100 \mathrm{hPa}$ was determined. Subsequently, the samples were dried at $105^{\circ} \mathrm{C}$ for $24 \mathrm{~h}$, for the determination of dry weight. The volume corresponding to macroporosity (Ma), microporosity (Mi), total porosity $(\mathrm{Pt})$ and soil density (Ds) were calculated according to EMBRAPA (1997).

To determine soil resistance to penetration (Rp) an impact penetrometer was used according to Stolf (1991). At each sampling point a determination of $\mathrm{Rp}$ was performed, considering the $0-0.20 \mathrm{~m}$ layer. At the same time, samples of the deformed structure were collected by means of a Dutch trench in the same layer and position to determine soil gravimetric moisture (Ug), and Ug was quantified using the method proposed by EMBRAPA (1997).

In the samples of deformed structure the hydrogenation potential in water $(\mathrm{pH})$, available phosphorus $(\mathrm{P})$, exchangeable potassium $(\mathrm{K})$, organic matter (OM), clay (Arg), silt (sil) and sand (Are) were determined, according to the methodology described by EMBRAPA (1997).

The grain yield $(\mathrm{Pg})$ was determined by means of the plants collected around each sampling point. A useful collection area formed by $1.1 \mathrm{~m}$ of width by $4 \mathrm{~m}$ of length was established, totaling a useful area of $4.4 \mathrm{~m}^{2}$. Subsequently, the productivity was extrapolated to an area of one hectare and corrected to a humidity condition of $13 \%$.

A descriptive analysis of the soil and soil properties was performed and the mean, median, maximum and minimum values, standard deviation and coefficient of variation were calculated. The coefficient of variation was classified according to the criteria established by Pimentel-Gomes and Garcia (2002). We also verified the hypothesis of normality of the data according to the Shapiro-Wilk test at $5 \%$ probability.

With the aim of identifying the set of soil properties that explained most of the variability in the area, principal component analysis (PCA) was performed. The data were standardized for mean 0 , variance 1 and analyzed separately in: (i) soil surface layer properties between $0-0.10 \mathrm{~m}\left(\mathrm{ACP}_{\mathrm{a}}\right)$ and (ii) soil sub-surface layer properties between $0.10-0.20 \mathrm{~m}\left(\mathrm{ACP}_{\mathrm{b}}\right)$. Selection of the number of main components was based on the criterion of analysis of the approximation quality of the correlation matrix, called the Kaiser method or Latent Root Method, using the components associated with eigenvalues greater than 1 (HAIR et al., 2005; MINGOTI, 2007; SILVA; LIMA; CÂNDIDO, 2010).

The data of the $\mathrm{Pg}$ and the scores of the main components obtained in the $\mathrm{ACP}_{\mathrm{a}}$ and $\mathrm{ACP}_{\mathrm{b}}$ were submitted for geostatistical analysis, which consisted of the modeling of semivariograms. The classification of the spatial dependence evaluator (ADE) was made based on the ratio between the nugget effect and the plateau $(\mathrm{C} / \mathrm{C}+\mathrm{Co})$, according to which $\mathrm{ADE} \leq 25 \%$ indicates a weakly dependent spatial variable; $25 \%<\mathrm{ADE} \leq 75 \%$ indicates moderately dependent spatial variable; and ADE $>75 \%$ indicates a heavily dependent spatial variable (ZIMBACK, 2001). The final criterion for choosing the semivariogram model and the number of neighboring values used to predict values in non-sampled locations was the model that obtained the closest coefficient of angularity to 1 and a linear coefficient closer to 0 in the cross validation. Once the semivariograms were adjusted, ordinary kriging of the data for contour mapping was performed and the values were divided into three classes of 
equidistant intervals. Finally, we verified the spatial interdependence of $\mathrm{Pg}$ with the Cp's obtained in the $\mathrm{ACP}_{\mathrm{a}}$ and $\mathrm{ACP}_{\mathrm{b}}$ using the cross-semivariogram as a parameter for comparing the studied cases.

\section{RESULTS AND DISCUSSION}

\section{Descriptive analysis}

By means of the descriptive analysis of the plant properties (Table 1), it can be observed that the average productivity was $3.28 \mathrm{Mg} \mathrm{ha}^{-1}$, higher than the national average in the harvest of 2015/2016, which was $2.92 \mathrm{Mg} \mathrm{ha}^{-1}$ (CONAB, 2016). Although with high average, $\mathrm{Pg}$ ranged from 2.83 to $3.70 \mathrm{Mg} \mathrm{ha}{ }^{-1}$. Thus, it is evident that there are localities in the area with productivities below the national average, and as such require local investigation in an attempt to identify the limiting factors of production, thus defining specific management zones.

Table 1. Descriptive statistics of the physical and chemical properties/attributes of the Red-Yellow Dystrophic Latosol and soybean yield.

\begin{tabular}{|c|c|c|c|c|c|c|c|}
\hline \multirow{3}{*}{ Properties } & \multicolumn{7}{|c|}{ Descriptive statistical measures } \\
\hline & \multirow{2}{*}{ Mean } & \multirow{2}{*}{ Median } & \multicolumn{2}{|c|}{ Value } & \multicolumn{2}{|c|}{ Dispersion } & \multirow{2}{*}{$\frac{\mathrm{Df}^{3}}{\operatorname{Pr}<W}$} \\
\hline & & & Minimum & Maximum & \pm Error $^{1}$ & $\mathrm{Cv}^{2}$ & \\
\hline & \multicolumn{7}{|c|}{ Plant properties } \\
\hline $\operatorname{Pg}\left(\mathrm{Mg} \mathrm{ha}^{-1}\right)$ & 3.28 & 3.26 & 2.83 & 3.70 & 0.018 & 5.48 & $0.07^{\mathrm{N}}$ \\
\hline & \multicolumn{7}{|c|}{ Soil properties $(0-0.10 \mathrm{~m})$} \\
\hline $\operatorname{Ma}\left(\mathrm{m}^{3} \mathrm{~m}^{-3}\right)$ & 0.09 & 0.09 & 0.04 & 0.15 & 0.005 & 33.33 & $0.52^{\mathrm{N}}$ \\
\hline $\operatorname{Mi~}\left(\mathrm{m}^{3} \mathrm{~m}^{-3}\right)$ & 0.35 & 0.35 & 0.32 & 0.39 & 0.002 & 2.85 & $0.88^{\mathrm{N}}$ \\
\hline $\operatorname{Pt}\left(\mathrm{m}^{3} \mathrm{~m}^{-3}\right)$ & 0.44 & 0.45 & 0.41 & 0.49 & 0.003 & 4.54 & $0.15^{\mathrm{N}}$ \\
\hline $\operatorname{Ds}\left(\mathrm{Mg} \mathrm{m}^{-3}\right)$ & 1.14 & 1.14 & 1.04 & 1.24 & 0.009 & 3.50 & $0.40^{\mathrm{N}}$ \\
\hline $\mathrm{Rp}(\mathrm{MPa})$ & 4.82 & 4.32 & 2.39 & 9.37 & 0.270 & 31.12 & $0.02^{\mathrm{T}}$ \\
\hline $\mathrm{Ug}\left(\mathrm{kg} \mathrm{kg}^{-1}\right)$ & 0.26 & 0.27 & 0.22 & 0.34 & 0.004 & 7.69 & $0.25^{\mathrm{N}}$ \\
\hline Are $\left(\mathrm{g} \mathrm{kg}^{-1}\right)$ & 366.0 & 365.4 & 334.8 & 402.4 & 1.910 & 4.98 & $0.72^{\mathrm{N}}$ \\
\hline Sil $\left(\mathrm{g} \mathrm{kg}^{-1}\right)$ & 141.3 & 140.3 & 64.2 & 224.1 & 4.470 & 27.96 & $0.74^{\mathrm{N}}$ \\
\hline $\operatorname{Arg}\left(\mathrm{g} \mathrm{kg}^{-1}\right)$ & 492.6 & 488.0 & 386.0 & 590.0 & 5.270 & 10.41 & $0.63^{\mathrm{N}}$ \\
\hline $\mathrm{K}\left(\mathrm{mg} \mathrm{dm}^{-3}\right)$ & 7.74 & 7.10 & 2.90 & 15.10 & 1.140 & 46.38 & $0.06^{\mathrm{N}}$ \\
\hline $\mathrm{P}\left(\mathrm{mg} \mathrm{dm}^{-3}\right)$ & 3.90 & 2.79 & 0.15 & 14.41 & 0.740 & 98.46 & $0.00^{\mathrm{T}}$ \\
\hline $\mathrm{MO}\left(\mathrm{g} \mathrm{kg}^{-1}\right)$ & 27.8 & 27.3 & 19.4 & 41.3 & 0.100 & 22.66 & $0.05^{\mathrm{N}}$ \\
\hline \multirow[t]{2}{*}{$\mathrm{pH}$} & 5.53 & 5.48 & 5.22 & 5.98 & 0.040 & 3.79 & $0.28^{\mathrm{N}}$ \\
\hline & \multicolumn{7}{|c|}{ Soil properties $(0.10-0.20 \mathrm{~m})$} \\
\hline $\mathrm{Ma}\left(\mathrm{m}^{3} \mathrm{~m}^{-3}\right)$ & 0.11 & 0.11 & 0.08 & 0.15 & 0.003 & 9.09 & $0.60^{\mathrm{N}}$ \\
\hline $\operatorname{Mi}\left(\mathrm{m}^{3} \mathrm{~m}^{-3}\right)$ & 0.32 & 0.32 & 0.30 & 0.35 & 0.002 & 3.12 & $0.01^{\mathrm{T}}$ \\
\hline $\operatorname{Pt}\left(\mathrm{m}^{3} \mathrm{~m}^{-3}\right)$ & 0.44 & 0.43 & 0.41 & 0.48 & 0.003 & 2.27 & $0.36^{\mathrm{N}}$ \\
\hline Ds $\left(\mathrm{Mg} \mathrm{m}^{-3}\right)$ & 1.13 & 1.13 & 1.05 & 1.23 & 0.008 & 3.53 & $0.61^{\mathrm{N}}$ \\
\hline $\mathrm{Rp}(\mathrm{MPa})$ & 4.80 & 4.80 & 3.18 & 6.91 & 0.170 & 20.00 & $0.68^{\mathrm{N}}$ \\
\hline $\mathrm{Ug}\left(\mathrm{kg} \mathrm{kg}^{-1}\right)$ & 0.26 & 0.26 & 0.23 & 0.32 & 0.003 & 7.69 & $0.07^{\mathrm{N}}$ \\
\hline Are $\left(\mathrm{g} \mathrm{kg}^{-1}\right)$ & 336.3 & 333.4 & 298.2 & 382.6 & 2.480 & 6.86 & $0.28^{\mathrm{N}}$ \\
\hline Sil $\left(\mathrm{g} \mathrm{kg}^{-1}\right)$ & 112.7 & 120.3 & 63.0 & 157.7 & 3.350 & 26.37 & $0.26^{\mathrm{N}}$ \\
\hline $\operatorname{Arg}\left(\mathrm{g} \mathrm{kg}^{-1}\right)$ & 550.8 & 547.0 & 469.0 & 620.0 & 4.690 & 8.39 & $0.46^{\mathrm{N}}$ \\
\hline $\mathrm{K}\left(\mathrm{mg} \mathrm{dm} \mathrm{m}^{-3}\right)$ & 6.57 & 5.90 & 1.80 & 14.30 & 0.830 & 49.01 & $0.09^{\mathrm{N}}$ \\
\hline $\mathrm{P}\left(\mathrm{mg} \mathrm{dm}^{-3}\right)$ & 1.35 & 0.51 & 0.05 & 5.36 & 0.340 & 125.92 & $0.00^{\mathrm{T}}$ \\
\hline $\mathrm{MO}\left(\mathrm{g} \mathrm{kg}^{-1}\right)$ & 22.4 & 22.7 & 15.8 & 32.4 & 0.060 & 16.07 & $0.33^{\mathrm{N}}$ \\
\hline $\mathrm{pH}$ & 5.35 & 5.28 & 4.97 & 5.99 & 0.040 & 4.67 & $0.15^{\mathrm{N}}$ \\
\hline
\end{tabular}

${ }^{1}$ Mean standard error; ${ }^{2}$ Coefficient of variation (\%); ${ }^{3}$ Distribution of frequencies being ${ }^{\mathrm{N}}$ normal and ${ }^{\mathrm{T}}$ tending to normal at 0.05 probability. 
In relation to the physical properties of the soil, it was verified that the Ma of the superficial layer was on average $0.09 \mathrm{~m}^{3} \mathrm{~m}^{-3}$, inferior to the average found for the sub-superficial layer (Table 1). This value exceeded the limit considered restrictive to the adequate aeration of the soil (REICHERT; SUZUKI; REINERT, 2007), and unsuitable for the root growth of the crops (TANG et al., 2011). However, the amplitude of Ma varied between 0.04 and $0.15 \mathrm{~m}^{3} \mathrm{~m}^{-3}$, considering the two layers of the soil. Therefore, there are sites in the area with macroporosity values well below $10 \%$, possibly restricting soil air diffusion, respiration and root growth (DEEPAGODA et al., 2011), being one of the possible soil factors that is restrictive to productivity.

Unlike Ma, Mi was higher in the topsoil, with a mean of $0.35 \mathrm{~m}^{3} \mathrm{~m}^{-3}$ (Table 1). According to Freddi et al. (2007), the surface compaction tends to decrease the pore diameter in the soil, due to the disorganization of the macropores present between the structural units of the aggregates, thereby transforming them into micropores. This assertion can be confirmed by $\mathrm{Pt}$, and it did not vary among the soil layers. However, this increase in micropore volume may not result in an increase in available water, this being dependent on the pore diameter that has been added to Mi.

The values of $\mathrm{Rp}$ were similar for the two layers analyzed, with a mean of 4.81 MPa (Table 1), being above the critical limit of $2 \mathrm{MPa}$ considered as restrictive to the growth of the root and shoot of the plants (TORMENA; SILVA; LIBARDI, 1998; REICHERT; SUZUKI; REINERT, 2007). However, a high amplitude for $\mathrm{Rp}$ was observed with values of up to $9.37 \mathrm{MPa}$. High amplitudes of Rp were also verified by Carvalho et al. (2006) in Red Latosol, cultivated under direct seeding (no-tillage system), with a variation of 0.549 to $4.33 \mathrm{MPa}$. The authors attributed such variation to the absence of soil preparation, traffic of agricultural machinery and the use of furrow stems for the deposition of fertilizers, instilling in the soil high variability in the physical properties.

In order to determine the $\mathrm{Rp}$ of the field, by means of an impact penetrometer, it is recommended that the soil be with two thirds of the micropores filled with water, that is, a condition of friable consistency of the soil, which was attended with an average $\mathrm{Ug}$ of $0.26 \mathrm{~kg} \mathrm{~kg}$ in the two layers (Table 1). Another factor that must be considered for the use of the impact penetrometer is that the soil moisture is constant due to its influence on the resistance values, i.e, the higher the soil moisture the lower its resistance and vice versa. Therefore, the soil moisture condition was ideal for field determination, which can be confirmed by its low coefficient of variation of $7.69 \%$.

In relation to the soil texture, it has been verified that a higher clay content exists in the
$0.10-0.20 \mathrm{~m}$ layer, and as a result, larger amounts of sand and silt can be found in the surface layer of the Latosol. This variation occurs between the layers of small magnitude when compared to the granulometric variations found within the same layer.

For clay, in the $0-0.10 \mathrm{~m}$ layer, a change from 386.0 to $590.0 \mathrm{~g} \mathrm{~kg}^{-1}$ was observed, and for sand a change from 298.2 to $382.6 \mathrm{~g} \mathrm{~kg}^{-1}$ was recorded. It is known that texture can alter soil aggregation, porosity, density as well as the volume of water retained by the soil and available to plants, in addition to the retention capacity of clay ions.

To characterize soil fertility, the criteria established by Sousa and Lobato (2004) were used. In relation to soil acidity, the average $\mathrm{pH}$ value of the surface layer was above 5.5, and this was considered ideal for nutrient availability to the plants and neutralization of the exchangeable aluminum. For a layer of $0.10-0.20 \mathrm{~m}$, the $\mathrm{pH}$ was less than ideal. However, it has been verified by the amplitude of the $\mathrm{pH}$ that there were areas with $\mathrm{pH}$ below and above the value of 5.5 for the two studied layers, demonstrating that acidity conditions are inadequate for the growth of the plants.

The levels of $\mathrm{P}$ and $\mathrm{K}$ were considered low (Table 1), the critical levels for this type of soil is from $8 \mathrm{mg} \mathrm{dm}^{-3}$ for $\mathrm{P}$ and $41 \mathrm{mg} \mathrm{dm}^{-3}$ for $\mathrm{K}$. In addition, the coefficients of variation of these properties were classified as very high in the two studied layers, demonstrating heterogeneity in soil fertility, which is due to the fertilizations performed on the surface.

In relation to $\mathrm{OM}$, the contents were classified as average in the two layers (Table 1). Although satisfactory due to the no-tillage system, the high coefficients of variation indicated the existence of sites with values below $20.1 \mathrm{~g} \mathrm{~kg}^{-1}$, which are classified as low.

The Shapiro-Wilk test confirmed normal distribution for all properties evaluated, with the exception of $\mathrm{Rp}$ and $\mathrm{P}$ in the soil surface layer, as well as the $\mathrm{Mi}$ and $\mathrm{P}$ in the sub-surface layer. Although the test was significant for these properties, indicating deviations in normality, it was considered that these data presented a distribution tending to normality. This can be justified by the proximity between the mean and median of these properties (Table 1).

\section{Multivariate geostatistical analysis}

The soil properties were separated according to the $0-0.10$ and $0.10-0.20 \mathrm{~m}$ layers, and later submitted for analysis of principal components, named $\mathrm{ACP}_{\mathrm{a}}$ and $\mathrm{ACP}_{\mathrm{b}}$, respectively. It was verified that all the properties of the soil in the two studied layers presented eigenvectors with weight greater than 0.50 , being considered highly significant (SILVA et al., 2015), in one of the nine established 
Cp's. With this, all soil properties were maintained in the analysis.

In the $\mathrm{ACP}_{\mathrm{a}}, 4$ main components $(\mathrm{Cp}$ 's) were extracted, which together represented $70.26 \%$ of the total variance in the area (Table 2). It was observed that $60.34 \%$ of this total was represented by only three components, and these were of greater representativeness and relevance in the correlation matrix. The latter component presented a low eigenvalue, close to 1 , and explained variance lower than $10 \%$, reflecting lower information quality.

Table 2. Results of the main component analysis applied to the physical and chemical properties of the Red-Yellow Latosol.

\begin{tabular}{cccc}
\hline Principal component $^{1}$ & Auto-value & Variance (\%) & Accumulated variance (\%) \\
\hline & & $0-0.10 \mathrm{~m}$ & \\
Cp1a & 3.05 & 23.53 & 23.53 \\
Cp2a & 2.68 & 20.63 & 44.16 \\
Cp3a & 2.10 & 16.18 & 60.34 \\
Cp4a & 1.28 & 9.91 & 70.26 \\
& & $0.10-0.20 m$ & \\
Cp1b & 3.37 & 25.97 & 25.97 \\
Cp2b & 2.06 & 15.90 & 41.87 \\
Cp3b & 1.81 & 13.99 & 55.87 \\
Cp4b & 1.35 & 10.44 & 66.31 \\
Cp5b & 1.07 & 8.28 & 74.59 \\
\hline
\end{tabular}

${ }^{1} \mathrm{Cp} 1 \mathrm{a}, \mathrm{Cp} 2 \mathrm{a}, \mathrm{Cp} 3 \mathrm{a}, \mathrm{Cp} 4 \mathrm{a}$ : First, second, third and fourth main components, respectively, for the group of attributes/properties of the soil surface layer; Cp1b, Cp2b, Cp3b, Cp4b, Cp5b: first, second, third, fourth and fifth main components, respectively, for the sub-surface soil properties group.

Regarding $\mathrm{ACP}_{\mathrm{b}}, 5$ PCs were obtained, which explained $74.59 \%$ of the total variance (Table 2 ). It was verified that the first two components of this analysis presented eigenvalues superior to 2, summarizing more than $40 \%$ of all the variance. The other Cp's of this analysis presented cumulative variance lower than $18.72 \%$. With this, it is evident that from the third component the amount of information retained for the sub-surface layer is small.

The geostatistical analysis was carried out with the purpose of mapping the spatial variability of grain yield and the Cp's scores obtained in the ACP's. Thus, spatial dependence was observed for $\mathrm{Pg}$ and for the components Cp1a, Cp3a, Cp4a, Cp1b, $\mathrm{Cp} 4 \mathrm{~b}$ and $\mathrm{Cp} 5 \mathrm{~b}$, fitting the spherical, gaussian and exponential models (Table 3 ). The others presented a pure nugget effect, indicating random spatial distribution within the sampling scales used.

The spatial dependency evaluator (ADE) was classified as moderate for $\mathrm{Cp} 1 \mathrm{a}$ and $\mathrm{Cp} 3 \mathrm{a}$, with the other main components and Pg being classified as having high spatial dependence, differing mainly in the achieved ranges (Table 3 ).

The range indicates the stabilization of semivariance when the threshold is reached. Through this parameter, it can be observed that the Pg data and the Cp's scores presented values ranging from 34.20 to $208.01 \mathrm{~m}$ (Table 3). All Cp's, with the exception of $\mathrm{Cp} 3 \mathrm{a}$, had lower reaches than $\mathrm{Pg}$, indicating the smaller spatial continuity of soil properties in relation to productivity.

Through cross-validation, it was possible to verify the quality of semivariogram adjustments. All $\mathrm{Cp}$ 's and $\mathrm{Pg}$, with the exception of $\mathrm{Cp} 5 \mathrm{~b}$, presented satisfactory kriging interpolation, since the angular coefficients (b), referring to the linear model between the observed and estimated values, were higher than 0.90 . Just as the linear coefficients (a) were close to zero, except for Pg.

The spatial correlation between the Pg and the Cp's obtained was tested by the cross-semivariogram formation, which was achieved between $\mathrm{Cpla}$ and $\mathrm{Cp} 1 \mathrm{~b}$ versus $\mathrm{Pp}$. With this, it was verified that the spatial variability of $\mathrm{Pg}$ showed a direct correlation with the spatial distribution of the attributes contained in Cpla and Cplb. The crosssemivariograms were adjusted to the spherical and Gaussian models, with a range of 61.61 and 253.57 $\mathrm{m}$, respectively, and high spatial dependence.

\section{Kriging Maps}

Pg data and scores of Cpla and Cplb were interpolated by means of ordinary kriging (Figure 2), using the fitted models for the single semivariograms. 
Table 3. Parameters of the semivariograms adjusted for the main components obtained in the multivariate analysis of the physical and chemical attributes of the Latosol and soybean yield.

\begin{tabular}{|c|c|c|c|c|c|c|c|c|c|c|c|}
\hline \multirow{3}{*}{ Principal component } & \multicolumn{11}{|c|}{ Parameter adjustment ${ }^{1}$} \\
\hline & \multirow{2}{*}{ Mod } & \multirow{2}{*}{ Co } & \multirow{2}{*}{$\mathrm{Co}+\mathrm{C}$} & \multirow{2}{*}{ Ao } & \multirow{2}{*}{$r^{2}$} & \multirow{2}{*}{ SQR } & \multicolumn{2}{|c|}{$\mathrm{ADE}^{2}$} & \multicolumn{3}{|c|}{ Cross-validation } \\
\hline & & & & & & & $\%$ & Class & $\mathrm{a}$ & $\mathrm{b}$ & $\mathrm{r}$ \\
\hline & \multicolumn{11}{|c|}{$\gamma(h)$ Simple ACPa } \\
\hline Cpla & esf & 0.28 & 1.01 & 78.60 & 0.50 & 0.13 & 72 & MO & -0.02 & 1.09 & 0.58 \\
\hline Cp2a & epp & 0.99 & 0.99 & - & - & - & - & - & - & - & - \\
\hline $\mathrm{Cp} 3 \mathrm{a}$ & gau & 0.54 & 1.08 & 208.01 & 0.72 & 0.09 & 50 & MO & -0.01 & 0.93 & 0.48 \\
\hline \multirow[t]{2}{*}{$\mathrm{Cp} 4 \mathrm{a}$} & $\exp$ & 0.23 & 1.06 & 86.40 & 0.23 & 0.32 & 78 & $\mathrm{AL}$ & -0.01 & 0.94 & 0.36 \\
\hline & \multicolumn{11}{|c|}{$\gamma(h)$ simple $A C P b$} \\
\hline Cplb & $\exp$ & 0.14 & 0.91 & 58.50 & 0.24 & 0.17 & 84 & $\mathrm{AL}$ & -0.01 & 0.92 & 0.31 \\
\hline $\mathrm{Cp} 2 \mathrm{~b}$ & epp & 1.00 & 1.00 & - & - & - & - & - & - & - & - \\
\hline $\mathrm{Cp} 3 \mathrm{~b}$ & epp & 0.91 & 0.91 & - & - & - & - & - & - & - & - \\
\hline $\mathrm{Cp} 4 \mathrm{~b}$ & $\exp$ & 0.21 & 1.00 & 34.20 & 0.07 & 0.08 & 79 & $\mathrm{AL}$ & -0.06 & 0.75 & 0.21 \\
\hline \multirow[t]{2}{*}{$\mathrm{Cp} 5 \mathrm{~b}$} & $\exp$ & 0.23 & 1.05 & 71.70 & 0.29 & 0.23 & 78 & $\mathrm{AL}$ & -0.02 & 0.57 & 0.24 \\
\hline & \multicolumn{11}{|c|}{$\gamma(h)$ simple plant attributes/properties } \\
\hline \multirow[t]{2}{*}{$\mathrm{Pg}$} & $\exp$ & 0.00 & 0.013 & 132.30 & 0.56 & 0.00 & 78 & $\mathrm{AL}$ & 0.18 & 0.94 & 0.54 \\
\hline & \multicolumn{11}{|c|}{$\gamma(h)$ Crossed-semivariogran } \\
\hline$P g=f(C p l a)$ & esf & -0.00 & -0.02 & 61.61 & 0.15 & 0.00 & 91 & $\mathrm{AL}$ & 2.26 & 0.31 & 0.35 \\
\hline$P g=f(C p 1 b)$ & gau & -0.00 & -0.01 & 253.57 & 0.11 & 0.00 & 99 & $\mathrm{AL}$ & 2.45 & 0.26 & 0.25 \\
\hline
\end{tabular}

${ }^{1}$ Mod: esf: spherical model; gau: Gaussian model; exp: exponential model; epp: pure nugget effect; Co, Co $+\mathrm{C}$ and Ao $(\mathrm{m})$ are respectively: nugget, range and reach effect; SQR: sum of squares of residues. ${ }^{2} \mathrm{ADE}$ : spatial dependence evaluator, where MO: moderate spatial dependence and AL: high spatial dependence.

CP1a summarized $23.53 \%$ of the total variance of soil properties in the $0-0.10 \mathrm{~m}$ layer. This $\mathrm{CP}$ showed a positive correlation with the variability of silt, $\mathrm{pH}, \mathrm{P}, \mathrm{K}$ and $\mathrm{Rp}$, and negatively with clay and $\mathrm{Ug}$. In this $\mathrm{Cp}$, it was observed that the class of the scores between -1.90 and 0.10 corresponded to $51.57 \%$ of the area, indicating the highest levels of clay and Ug, proving the effect of clay on soil water retention (Figure 2). In this range, the clay content varied between 446.0 and $590.0 \mathrm{~g} \mathrm{~kg}^{-1}$, and $\mathrm{Ug}$ between 0.28 and $0.34 \mathrm{~kg} \mathrm{~kg}^{-1}$, with the lowest values of $\mathrm{Rp}$ being found between 2.39 and $4.90 \mathrm{MPa}$. In this region, the worst fertility conditions were also verified, with variations in soil $\mathrm{pH}$ between 5.22 and 5.48 and $\mathrm{K}$ and $\mathrm{P}$ levels available between 2.90 and $9.30 \mathrm{mg} \mathrm{dm}^{-3}$ and 0.15 to $6.36 \mathrm{mg} \mathrm{dm}^{-3}$, respectively.

Scores above 0.10 in $\mathrm{CP} 1 \mathrm{a}$ represented $48.43 \%$ of the area (Figure 2), with clay and $\mathrm{Ug}$ contents ranging from 386.0 to $445.0 \mathrm{~g} \mathrm{~kg}^{-1}$ and 0.22 and $0.27 \mathrm{~kg} \mathrm{~kg}^{-1}$, respectively. Being the region of the map with the best fertility condition, $\mathrm{pH}$ oscillating between 5.50 and $5.98, \mathrm{~K}$ content between 9.31 and $15.10 \mathrm{mg} \mathrm{dm}^{-3}$, and $\mathrm{P}$ between 6.37 and $14.41 \mathrm{mg} \mathrm{dm}^{-3}$.
The main component of the sub-surface layer of the soil ( $\mathrm{Cp} 1 \mathrm{~b}$ ) explained $25.97 \%$ of the total data variance in the $\mathrm{ACPb}$, correlating positively to the properties sand, silt, $\mathrm{pH}, \mathrm{K}, \mathrm{Rp}$, and negatively to clay and Ug (Figure 2).

According to the $\mathrm{Cplb}$ map, the class represented by the scores between -1.79 and 0.03 corresponded to $48.74 \%$ of the area, indicating the worst conditions of active acidity and fertility for this layer, with variations in $\mathrm{pH}$ between 4.97 and $5.19, \mathrm{~K}$ content between 1.80 and $6.60 \mathrm{mg} \mathrm{dm}^{-3}$. In this interval, the highest clay and Ug contents were observed. The clay variation was 571.0 and $620.0 \mathrm{~g} \mathrm{~kg}^{-1}$ and $\mathrm{Ug}$ between 0.28 and $0.32 \mathrm{~kg} \mathrm{~kg}^{-1}$. This resulted in lower values of $\mathrm{Rp}$ in this region that were 3.18 and $5.04 \mathrm{MPa}$.

By means of the CP1b map, it can be seen that $51.26 \%$ of the area presented scores greater than or equal to 0.03 , corresponding to the area with the best fertility condition. In this region, $\mathrm{pH}$ and $\mathrm{K}$ values were between 5.20 and 5.99, and 6.61 and $14.30 \mathrm{mg} \mathrm{dm}^{-3}$, respectively. However, in this region the highest $\mathrm{Rp}$ values were observed, ranging from 5.05 to $6.91 \mathrm{MPa}$. 


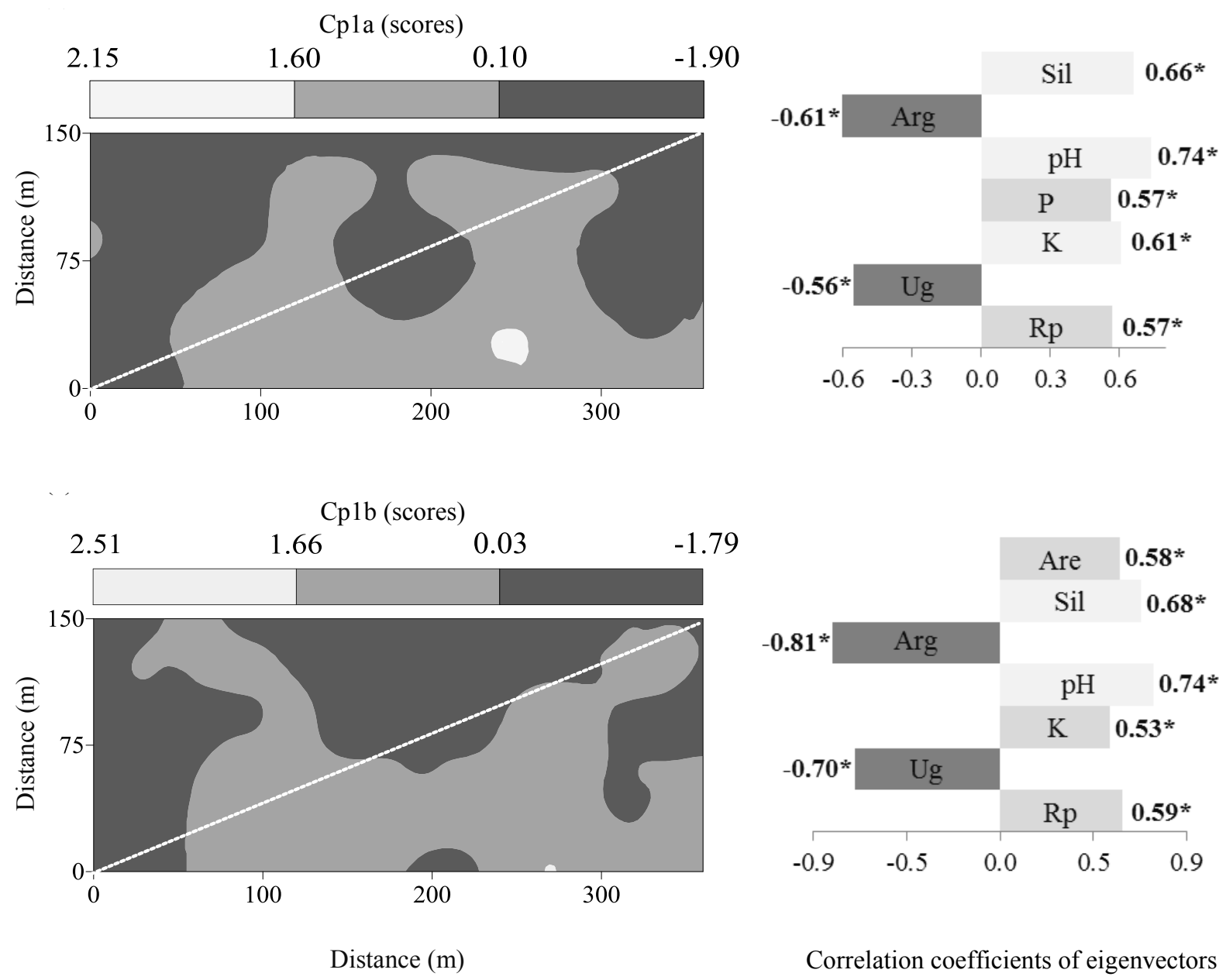

Figure 2. Spatial distribution maps of the main components of the Red-Yellow Dystrophic Latosol and correlation coefficients of the eigenvectors.

It was observed that the variability of the physical and chemical properties in the two layers is similar (Figure 2). There is an area with higher clay content, Ug and lower values of Rp, and another region with better fertility, however, with higher values of $\mathrm{Rp}$.

Due to the kriging map of $\mathrm{Pg}$, it was possible to define two areas of productivity (Figure 3). It was verified that $52.10 \%$ of the area presented productivities varying between 2.83 to $3.28 \mathrm{Mg} \mathrm{ha}^{-1}$, this being the region of lower productivity. The other $47.9 \%$ of the area presented productivities between 3.29 and $3.70 \mathrm{Mg} \mathrm{ha}^{-1}$. Thus, it was possible to identify the "problem" area, thus determining a management zone as a function of crop productivity (Figure 3).

According to CPs, the lowest yields obtained in the "management zone" occurred due to fertility limitation (Figures 2 and 3). It was observed that outside the "management zone" the fertility condition was better, even with higher values of Rp. Therefore, it can be stated that $\mathrm{Rp}$ was not limiting to Pg. This can be explained mainly by the amount of rainfall and its distribution in the soybean growing season in the north of Mato Grosso, minimizing the effects of compaction. Another point to be considered is the lower content of clay outside the "management zone", which resulted in the retention of a smaller amount of water by the soil, and even greater productivities were verified outside the "management zone".

It was also verified by the Pg map (Figure 3) that small areas presented yields above $3.4 \mathrm{Mg} \mathrm{ha}^{-1}$, evidencing that this soybean cultivar has the potential of reaching higher yields in the entire area, even outside the "management zone" as long as the limitations of fertility and compaction are solved, thus raising the average productivity. 


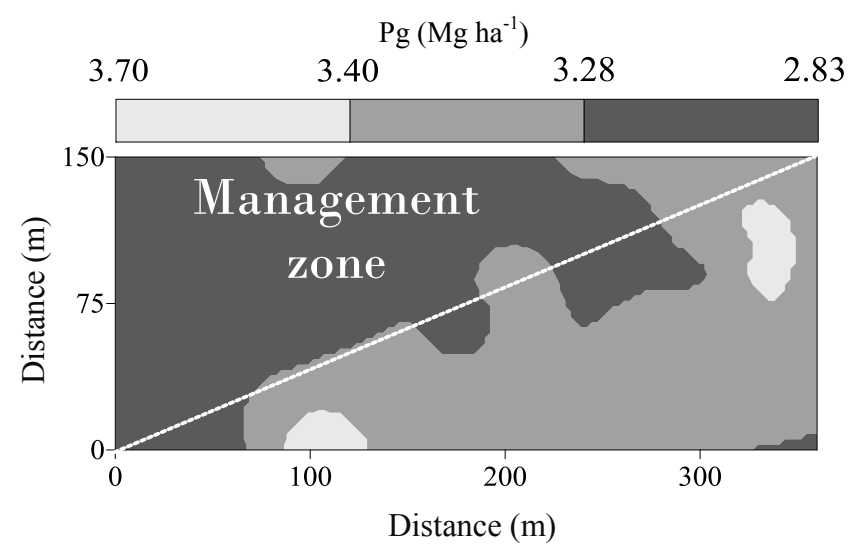

Figure 3. Spatial distribution map of soybean yield $(\mathrm{Pg})$ cultivated in a Red-Yellow Dystrophic Latosol submitted to the direct seeding system.

The multivariate analysis associated with geostatistics allowed us to summarize, map and interpret the physical and soil fertility conditions, thus delimiting management zones as a function of grain yield. The importance of precision agriculture can be seen in the management of large farms, such as those in the north of Mato Grosso, where a physical variability is observed in the stands, especially in relation to texture and soil fertility. It was inferred that the management of these areas should not be performed due to the average data obtained in the plots, let alone consider that the soils, mainly of sedimentary origin like those of the region, are homogeneous. Thus, the fertilization operations, establishment of the number of plants per hectare and soil preparation, among others, should be carried out according to the natural variability of the soils.

\section{CONCLUSIONS}

The practice of direct seeding associated with soybean / corn succession for 11 years caused changes in the structure of the variance and covariance of the physical and chemical properties of the soil surface layer, and was detected by analysis of the main components.

The physical and chemical properties of the soil are summarized in two main components that correlate with soybean productivity. The structure of the spatial variability of the main components and the soybean productivity, as well as of the crossed semivariograms, fit the exponential and spherical models, with moderate to high spatial dependence.

Among the physical and chemical properties evaluated, $\mathrm{pH}, \mathrm{K}$ and $\mathrm{P}$ represent the set of soil properties that more clearly explain the variability of soybean yield.

The use of principal component analysis associated with geostatistics demonstrated that kriging maps have the potential of being used as a tool in the definition of homogeneous areas of management, mainly for the recovery of degraded soils. Becoming a useful and accessible tool for the farmer in soil management and crop productivity.

\section{REFERENCES}

CARVALHO, G. J. et al. Correlação da produtividade do feijão com a resistência à penetração do solo sob plantio direto. Revista Brasileira de Engenharia Agrícola e Ambiental, Campina Grande, v. 10, n. 3, p. 765-771, 2006.

COMPANHIA NACIONAL DE ABASTECIMENTO - CONAB. Acompanhamento da safra brasileira: Grãos: safra 2015/2016: Oitavo levantamento. Disponível em: <www.conab.gov.br>. Acesso em: 20 de jun. 2016.

DEEPAGODA, T. K. K. et al. Density-corrected models for gas diffusivity and air permeability in unsaturated soil. Vadose Zone Journal, Madison, v. 10, n. 1, p. 226-238, 2011.

EMPRESA BRASILEIRA DE PESQUISA AGROPECUÁRIA - EMBRAPA. Centro Nacional de Pesquisa de Solos. Manual de métodos de análise de solo. 2. ed. Rio de Janeiro, RJ: Embrapa, 1997. $212 \mathrm{p}$.

EMPRESA BRASILEIRA DE PESQUISA AGROPECUÁRIA - EMBRAPA. Sistema brasileiro de classificação de solos. 4. ed. Brasília, DF: Embrapa Brasília, 2014. 302 p.

FREDDI, O. S. et al. Compactação do solo e intervalo hídrico ótimo no crescimento e na produtividade da cultura do milho. Bragantia, Campinas, v. 66, n. 3, p. 477-486, 2007.

HAIR, J. F. et al. Análise multivariada de dados. 5. ed. Porto Alegre, RS: Bookman, 2005. 597 p.

JESUS LACERDA, J. J. et al. Adubação, 
produtividade e rentabilidade da rotação entre soja e milho em solo com fertilidade construída. Pesquisa Agropecuária Brasileira, Brasília, v. 50, n. 9, p. 769-778, 2015.

LUCIANO, R. V. et al. Atributos físicos relacionados à compactação de solos sob vegetação nativa em região de altitude no sul do Brasil. Revista Brasileira de Ciência do Solo, Viçosa, v. 36, n. 6, p. 1733-1744, 2012.

MINGOTI, S. A. Análise de dados através de métodos de estatística multivariada: uma abordagem aplicada. 1. ed. Belo Horizonte, MG: Editora UFMG; 2007. 295 p.

PIMENTEL-GOMES, F.; GARCIA, C. H. Estatística aplicada a experimentos agronômicos e florestais: exposição com exemplos e orientações para uso de aplicativos. Piracicaba, SP: Fealq, 2002. 309 p.

REICHERT, J. M.; SUZUKI, L. E. A. S.; REINERT, D. J. Compactação do solo em sistemas agropecuários e florestais: identificação, efeitos, limites críticos e mitigação. In: CERRETA, C. A.; SILVA, L. S.; REICHERT, J. M. (Eds.). Tópicos em ciência do solo. Viçosa: Sociedade Brasileira de Ciência do Solo, 2007. v. 5, cap.2, p. 49-134.

SANTOS, D. R.; GATIBONI, L. C.; KAMINSKI, J. Fatores que afetam a disponibilidade do fósforo e o manejo da adubação fosfatada em solos sob sistema plantio direto. Ciência Rural, Santa Maria, v. 38, n. 2, p. 576-586, 2008.

SILVA, E. N. S. et al. Variabilidade de atributos físicos e químicos do solo e produção de feijoeiro cultivado em sistema de cultivo mínimo com irrigação. Revista Brasileira de Ciência do Solo, Viçosa, v. 39, n. 2, p. 598-607, 2015.

SILVA, S. A.; LIMA, J. S. S.; CÂNDIDO, A. Variabilidade espacial de atributos químicos de um Latossolo Vermelho-Amarelo húmico cultivado com café. Revista Brasileira de Ciência do Solo, Viçosa, v. 34, n. 1, p. 15-22, 2010.

SOIL SURVEY STAFF. Keys to soil taxonomy. 12. ed. Washington, DC: United States Department of Agriculture, Natural Resources Conservation Service, 2014. 360 p.

SOUSA, D. M. G.; LOBATO, E. Cerrado: correção do solo e adubação. 2. ed. Brasília, DF: Embrapa Informações Tecnológicas, 2004. 416 p.

SOUZA, A. P. et al. Classificação climática e balanço hídrico climatológico no estado de Mato Grosso. Nativa, Sinop, v. 1, n. 1, p. 34-43, 2013.
STOLF, R. Teoria e teste experimental de fórmulas de transformação dos dados de penetrômetro de impacto em resistência do solo. Revista Brasileira de Ciência do Solo, Viçosa, v. 15, n. 3, p. 229-235, 1991.

STRECK, C. A. et al. Modificações em propriedades físicas com a compactação do solo causada pelo tráfego induzido de um trator em plantio direto. Ciência Rural, Santa Maria, v. 34, n. 3, p. 755-760, 2004.

TANG, A. M. et al. A study on the air permeability as affected by compression of three French soils. Geoderma, Amsterdam, v. 162, n. 1, p. 171-181, 2011.

TORMENA, C. A.; SILVA, A. P. da; LIBARDI, P. L. Caracterização do intervalo hídrico ótimo de um Latossolo Roxo sob plantio direto. Revista Brasileira de Ciência do Solo, Viçosa, v. 22, n. 4, p. 573-581, 1998.

VALADÃO, F. C. A. et al. Adubação fosfatada e compactação do solo: sistema radicular da soja e do milho e atributos físicos do solo. Revista Brasileira de Ciência do Solo, Viçosa, v. 39, n. 1, p. 243-255, 2015.

ZIMBACK, C. R. L. Análise espacial de atributos químicos de solos para fins de mapeamento da fertilidade do solo. $2001.114 \mathrm{f}$. Tese (Livre-Docência) - Faculdade de Ciências Agronômicas, Universidade Estadual Paulista, Botucatu, 2001. 